\title{
Removal of Methylene Blue Using UV-C Pretreated Citrobacter freundii JH 11-2 and Bacillus pseudomycoides JH 2-2 Biomass
}

\author{
HaeWon Gim • Min Cho $\cdot$ Byung-Taek Oh* \\ Division of Biotechnology, Advanced Institute of Environment and Bioscience, College of Environmental \\ and Bioresource Sciences, Chonbuk National University
}

\begin{abstract}
In this study, we evaluated the methylene blue (MB) adsorption potential of non-treated and UV-C pretreated bacterial biomass from aqueous solution. The UV-C pretreatment denature the biomass and has increased overall functional groups when compared to non-treated biomass. The biosorbent was exposed to various $\mathrm{pH}$, biomass dose, and contact time. The results showed that the dried and UV-C pretreated biomass effectively removed MB within 30 min. Dried and UV-C pretreated biomass of Bacillus pseudomycoides JH 2-2 showed a adsorption of 858.2 and $1072.4 \mathrm{mg} / \mathrm{g}$ at optimum conditions (pH: 9.0, contact time: $30 \mathrm{~min}$, biomass dose: $1 \mathrm{~g} / \mathrm{L}$ ). Similarly, dried and UV-C pretreated biomass of Citrobacter freundii JH 11-2 showed an adsorption 868.3 and $954 \mathrm{mg} / \mathrm{g}$ at optimum conditions (pH: 9.0, contact time: 10 min, biomass dose: $1.5 \mathrm{~g} / \mathrm{L}$ ). The changes in the functional groups of UV-C pretreated biomass could be responsible for enhanced adsorption of MB. The results obtained have shown that non-treated and UV-C pretreated biomass has a high adsorption capacity for MB dye and can be used as a low-cost biosorbent in wastewater treatments.
\end{abstract}

Key words : UV-C, Biomass, Methylene blue, Adsorption, Biosorbent

\section{Introduction}

Synthetic dyes have been widely used in several industries like textile, carpet, rubber, paper, food, leather, plastics and cosmetic to color the product and attract the people for business. Over several thousands of commercially available dyes exist and are produced in tons per year (McMullan et al., 2001; Pearce et al., 2003; Crini, 2006). However, a rough estimation indicating that 10,000 tons of dyes are produced and $7 \times 10^{8} \mathrm{~kg}$ are used for several purposes per annum (Bayramoglu and Arica, 2007; Ip et al., 2009). Due to their good solubility, synthetic dyes are common water pollutants and they may frequently be found in trace quantities in industrial wastewater. The presence of very small amounts of dyes in water leads to several problems such as increasing the toxicity and COD (Chemical Oxygen Demand) of the effluent, reducing the light penetration, which are harmful to fish and other aquatic organisms (Arami, 2005; Crini, 2006). Several problems such as vomiting, profuse sweating, mental confusion, painful micturition, and methemoglobinemia are arising due to ingesting of dye contaminated water (Ghosh and Bhattacharyya, 2002; Avom et al., 1997). When the dye concentration reaches its saturation level in particular ecosystem, it become highly toxic and leads to a lethal effect (Eccles, 1995).

Numerous conventional physico-chemical treatments such as coagulation, precipitation, filtration, electrodialysis, membrane separation, electrocoagulation, reverse osmosis, nano filtration, titania photocatalyst and oxidation have been used to remove the dye from contaminated water (Morais et al., 1999; Chiou and Li, 2003; Guillard et al., 2003; Aleboyeh et al., 2008; Nataraj et al., 2009). However, these processes are too expensive and adsorption is one of effective methods to remove dyes from wastewater. Thus, the present study made an attempt to remove the dye from wastewater, by an effective and low-cost biophysical method (living or dead microorganisms and ultraviolet

*Corresponding author: btoh@jbnu.ac.kr

Received : 2014.4. 7 Reviewed : 2014. 4. 30 Accepted :2014. 4. 30

Discussion until : 2014. 6. 30 
pretreated). Earlier several pretreatment processes have been made to improve adsorption potential of the adsorbent (Aksu and Tezer, 2005; Vijayaraghavan and Yun, 2007). However, in our study an attempt using UV-C was used for pretreatment of bacterial biomass in order to improve adsorption capability. UV-C generally used for inactivating pathogenic microorganisms in sewage and drinking water (Zimmer and Slawson, 2002; Song et al., 2009). Since UV$\mathrm{C}$ has a short wavelength of $245 \mathrm{~nm}$ it generates oxygen radical and induces RNA/DNA damage (Widmann et al., 1998). The principal inactivation of UV-C is the formation of pyrimidine dimer between adjacent pyrimidine molecules on the same strand of DNA/RNA (Franz et al., 2009), also the sludge contains high concentration of guanine and adenosine (Sies et al., 1996).

The objectives of the present study were to (i) to assess the methylene blue (MB) adsorption potential of UV-C pretreated Citrobacter freundii $\mathrm{JH}$ 11-2, and Bacillus pseudomycoides $\mathrm{JH} 2-2$, (ii) assess the physico-chemical variables affecting optimal removal of $\mathrm{MB}$, and (iii) identify the functional groups of the bacteria before and after UV-C pretreatment in order to have a better understanding on the adsorption and desorption of MB.

\section{Materials \& Methods}

\subsection{Bacteria biomass preparation}

$C$. freundii JH 11-2 and B. pseudomycoides JH 2-2 were isolated from abandoned metal mine soil from Gyeongsangbuk-do. The culture medium was composed of $(\mathrm{g} / \mathrm{L})$ beef extract, 1.0; yeast extract, 2.0; peptone, 5.0; and sodium chloride, $5.0 \mathrm{~g}$. The $\mathrm{pH}$ of the medium was adjusted to 6.8 before autoclaving. The bacterial cultures were inoculated into the flasks, incubated at $30^{\circ} \mathrm{C}$ for $24 \mathrm{hr}$ with agitation speed at $130 \mathrm{rpm}$. After incubation, the biomass was harvested from the medium by centrifugation at $6359 \mathrm{xg}$ for $15 \mathrm{~min}$. The separated biomass was washed three times with distilled water and stored at $4^{\circ} \mathrm{C}$ for further study.

\subsection{Preparation of adsorbate}

MB used in this study was purchased from SigmaAldrich (St. Louis, MO, USA). The stock solution (100,000 $\mathrm{mg} / \mathrm{L}$ ) was prepared by dissolving $1.0 \mathrm{~g} \mathrm{MB}$ in $100 \mathrm{ml}$ distilled water; other concentrations were obtained by successive dilutions. The concentration of $\mathrm{MB}$ in the solution was analyzed by using a UV-Vis spectrophotometer (Agilent 8453 spectrophotometer, Agilent Technologies, Germany) with the absorption maxima at $668 \mathrm{~nm}$ (Hameed et al., 2007).

\subsection{Pretreatment of bacterial biomass by using UV light}

The bacterial biomass was dispersed in distilled water $(800 \mathrm{ml})$ and the optical density of the solution was adjusted to 0.9 at $600 \mathrm{~nm}$. A $4 \mathrm{~W}$ low-pressure lamp was used to emitting mainly at $254 \mathrm{~nm}$. The UV-C radiation was varied between 0.4 and $0.6 \mathrm{~mW} / \mathrm{cm}^{2}$ extending the exposure time up to $1 \mathrm{~h}$. Later, biomass was harvested from water by centrifugation at $6000 \mathrm{rpm}$ for $15 \mathrm{~min}$ and then dried at $70^{\circ} \mathrm{C}$.

\subsection{Biosorption experiment}

Batch studies were carried out by shaking $100 \mathrm{ml}$ of MB solution with different concentrations of biomass $(0.01$, $0.05,0.1,0.15,0.2 \mathrm{~g}$ ). The effect of $\mathrm{pH}$ on the adsorption of MB was determined at different initial $\mathrm{pH}$ levels $(3,5,7,9$ and 11). The $\mathrm{pH}$ of the solution was adjusted using basic acid and alkali before mixing the biomass. Samples were collected at predetermined time intervals $(0,10,20,30,60$, $90 \mathrm{~min}$ ) and centrifuged at $4000 \mathrm{rpm}$ for $3 \mathrm{~min}$, and the supernatant was analyzed for the dye concentration.

The biosorption capacities at equilibrium, $q_{e}(\mathrm{mg} / \mathrm{g})$, were calculated using the following equation

$$
q_{e}=\left(C_{o}-C_{e}\right) / M^{*} V
$$

where $C_{o}(\mathrm{mg} / \mathrm{L})$ and $C_{e}(\mathrm{mg} / \mathrm{L})$ are the initial and equilibrium concentrations of the dye, respectively. $V$ is the volume of the dye solution (L) and $M$ is the amount of biomass used (g).

All the experiments were done in triplicates and the results were interpreted statistically using Sigma Plot Software (Ver. 10.0).

\subsection{FT-IR analysis of control and UV treated biomass}

The Fourier transform infrared spectra (FTIR) of the control and UV-C pretreated biomass were obtained on a Perkin-Elmer FTIR spectrophotometer (USA) in the diffuse 
(a)

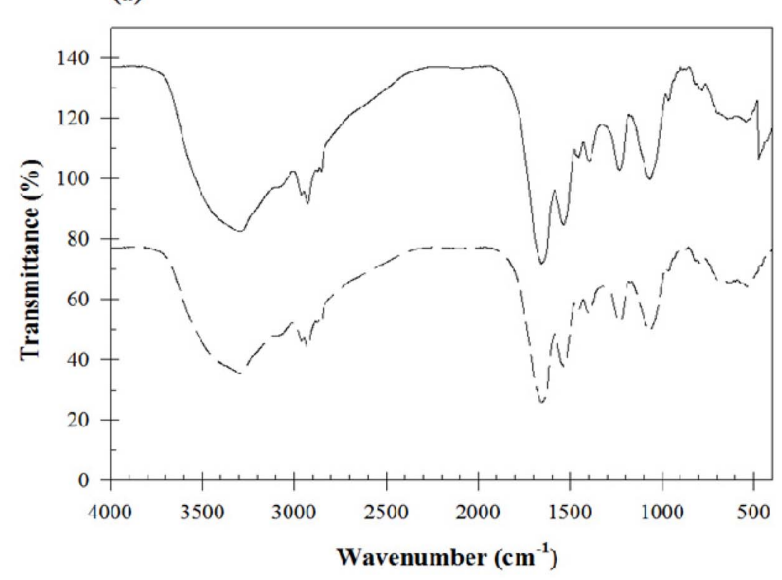

(b)

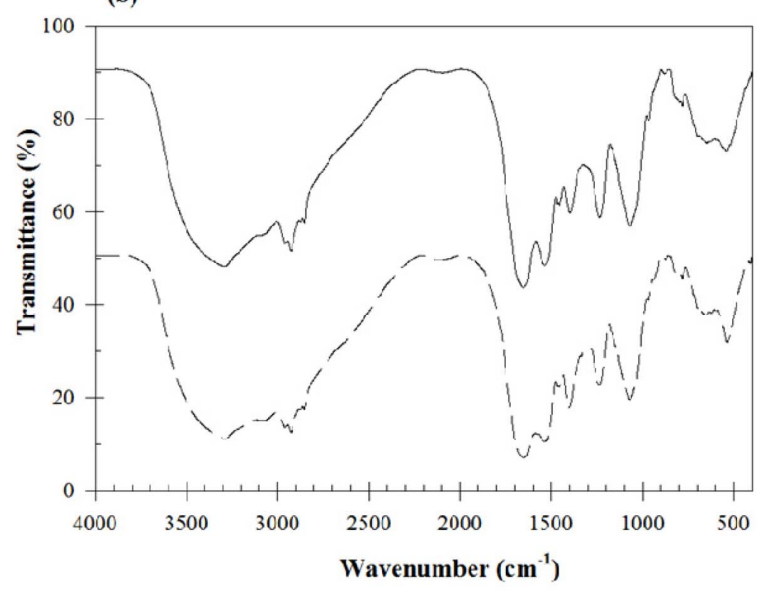

Fig. 1. (a) FT-IR spectrum of B. pseudomycoides JH 2-2 dried ( $\cdots$ ) and UV-C treated (-) (b) $C$. freundii JH 11-2 dried ( $\cdots$ ) and UVC treated (-).

reflectance mode at a resolution of $4 \mathrm{~cm}^{-1}$ in $\mathrm{KBr}$ pellets.

\section{Results and discussion}

\subsection{Properties of biomass}

In order to determine the functional groups present in the biomass, the FT-IR spectra of the native and UV-C pretreated biomass was obtained and the results are shown in Fig. 1. FT-IR results showed the presence of various functional groups on $B$. pusedomycoides $\mathrm{JH} \mathrm{2-2}$ and $C$. freundii $\mathrm{JH}$ 11-2 cell membrane. The broad peaks at 3,000 to $3500 \mathrm{~cm}^{-1}$ revealed hydroxyl groups (-OH) and 3,000 to $2850 \mathrm{~cm}^{-1}$ were C-H stretching vibration (Pavia et al., 2008). The peaks at 1725 to $1500 \mathrm{~cm}^{-1}$ could be $\mathrm{C}=\mathrm{O}$ groups in carboxyl and $\mathrm{N}-\mathrm{H}$ groups in amine, respectively. These results indicated that the presence of various functional

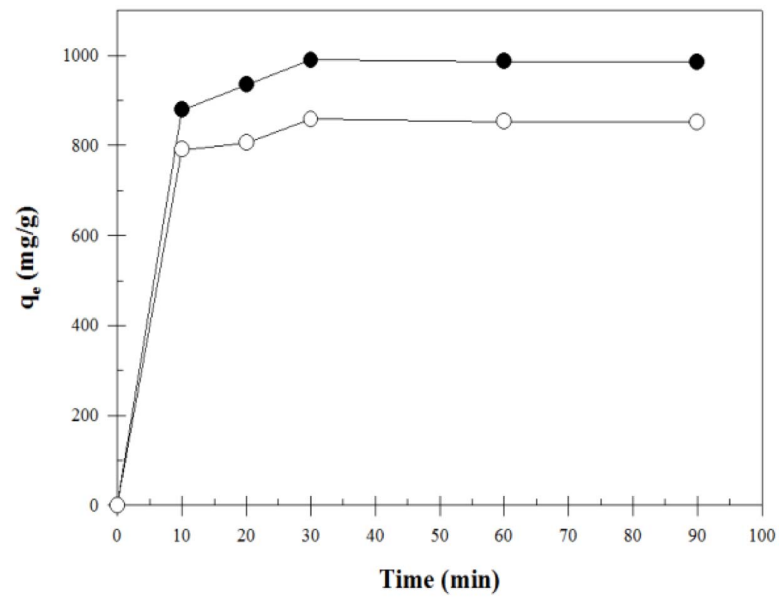

Fig. 2. Effect of the contact time on removal of MB by dried $(\bigcirc)$ and UV-C treated (O) B. pseudomycoides JH 2-2.

groups such as hydroxyl, carboxyl, and amine groups on surface of cell membrane which is potentially known to bind with dyes (Colak et al., 2009). When comparing with native biomass, UV-C pretreated biomass showed some functional group changes. A significant shift can be found in UV-C pretreated biomass (Fig. 1). For example the peaks around 1650, 1500 and $1400 \mathrm{~cm}^{-1}$ were shifted and/or broadened and which confirms the effective modification of the biomass.

\subsection{Effect of contact time}

Dye adsorption rapidly increased during the first $10 \mathrm{~min}$, and gradually increased with laps of time until it reaches the equilibrium (30 $\mathrm{min}$ ) (Fig. 2). The dye adsorption during the first 30 min was impressive for all the initial concentrations and attained 90 and $78 \%$ removal for UV-C pretreated and dead cells, respectively. After $60 \mathrm{~min}$ of initial contact time, a minor decrease in adsorption was observed. In general, UV-C pretreated biomass exhibited high adsorption rate than the dried biomass which could be attributed to the increase of binding sites on the biomass surface. The maximum rate of adsorption increased gradually within 10 $\min (878.9 \mathrm{mg} / \mathrm{g})$, followed by $20 \mathrm{~min}(934.5 \mathrm{mg} / \mathrm{g})$. After 20 minutes the rate of adsorption remained constant $(990.25$ $\mathrm{mg} / \mathrm{g})$.

\subsection{Effect of optimum pH}

$\mathrm{pH}$ is one of the most important factor to influence dye 


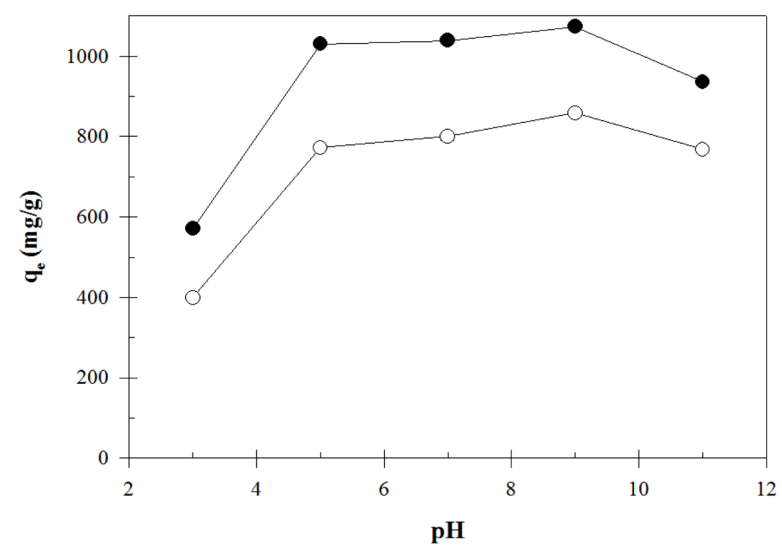

Fig. 3. Effect of initial $\mathrm{pH}$ on removal of $\mathrm{MB}$ by dried $(\bigcirc)$ and UV-C treated (O) B. pseudomycoides JH 2-2.

adsorption. According to $\mathrm{pH}$, functional groups located on the surface of the adsorbent were dissociated or protonated. The adsorption of MB by B. pseudomycoides JH 2-2 biomass was determined as a function of $\mathrm{pH}$ and the results are shown in Fig. 3. The removal rate was low at acidic $\mathrm{pH}$ $(\mathrm{pH} 2.0)$, gradually increases and reaches the maximum adsorption at $\mathrm{pH}$ 9. The high alkaline $\mathrm{pH}(9.0)$ generates negatively charged absorption sites (OH-) in the surface of the bacteria which enhances the adsorption of positively charged MB. However, a further increase in $\mathrm{pH}$ (10.0) decreased the adsorption rate of MB. The results are consistent with previous studies reported the enhanced adsorption of MB at pH 9.0 (Gupta et al., 2004; Janos, 2003).

The cell wall of the Gram-positive bacteria is different from Gram-negative bacteria. The Gram-positive bacteria consist of peptidoglycan layer connected by amino acid bridges (Mera et al., 1992). If Gram-positive bacteria exposed to nearly neutral or alkaline $\mathrm{pH}$ condition, the cells may get negative charge (Vijayaraghavan et al., 2008). However, MB is a cationic dye which may electrostatically attracted towards the negatively chared cell surface. Carboxyl group present in the cell wall of B. pseudomycoides JH 2-2 was also responsible for adsorption of $\mathrm{MB}$. The $\mathrm{P}_{\mathrm{ka}}$ value of the carboxyl group remains in the range of 3.6-4.5 (Romero González et al., 2001). The carboxyl group has negative charge at $\mathrm{pH} 5$ and electrostatically attracts $\mathrm{MB}$ towards bacterial biomass surface. At $\mathrm{pH}$ values below 5 , the carboxyl group was in positive charge which reduces the adsorption of $\mathrm{MB}$ onto biomass surface.

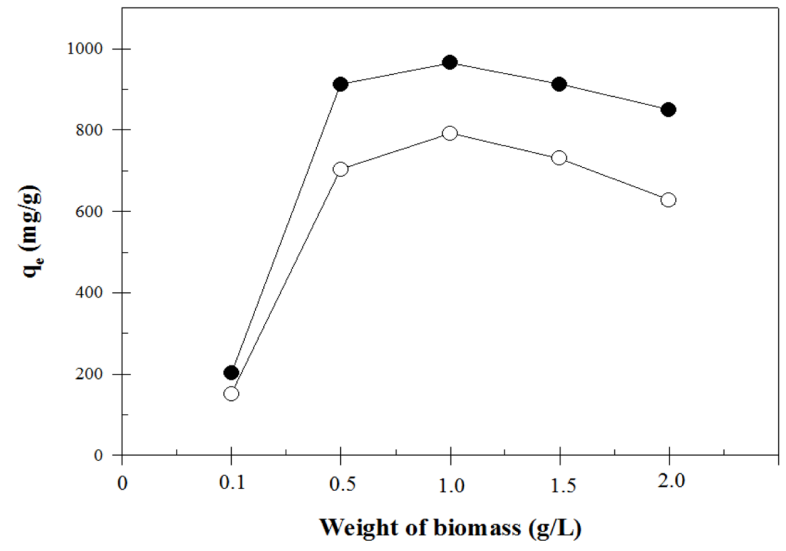

Fig. 4. Effect of biomass dose on removal of MB by dried ( $\bigcirc$ ) and UV-C treated (O) B. pseudomycoides JH 2-2.

\subsection{Effect of biosorbent dose}

The effect of adsorbent dosage for both native and UV-C pretreated biomass was evaluated and the results are shown in Fig. 4. The removal rate was increased with increase in adsorbent dosage up to $0.1 \mathrm{~g}$. However, a further increase in dosage to $0.2 \mathrm{~g}$ decreased the removal rate. Thus, the optimum dose of biomass for maximal removal of MB was determined as $1 \mathrm{~g} / \mathrm{L}$ with removal efficiency of $1072.39 \mathrm{mg} /$ g. Electrostatic interaction between biosorbent and $\mathrm{MB}$ could be responsible for adsorption. The poor adsorption rate at high adsorbent dose could be due to aggregation between biomass (Kumar and Porkodi, 2007). A higher adsorption obtained with a small amount of UV-C pretreated biosorbent could be attributed to an increase in the negative charged functional groups on the biosorbent surface.

\subsection{Biosorption potentials of $C$. freundii $\mathrm{JH}$ 11-2 and $B$. pseudomycoides $\mathrm{JH}$ 2-2}

The study bacteria $C$. freundii $\mathrm{JH} \quad 11-2$ and $B$. pseudomycoides JH 2-2 showed effective MB removal compared with other biomass (Table 1). The UV pretreated bacterial biomass showed maximum removal at optimum conditions ( $\mathrm{pH}$ 9.0; constant time $10 \mathrm{~min}$; biosorbent dose, $0.15 \mathrm{~g}$ ). The maximum biosorption $\mathrm{q}_{\mathrm{e}}$ of dried and UV-C pretreated biomass were $868.3 \mathrm{mg} / \mathrm{g}$ and $954 \mathrm{mg} / \mathrm{g}$, respectively (Fig. 5). The differences in the adsorption could be attributed to the differences in cell wall composition of the bacteria. The presence of high amount of peptidoglycon and low amount of lipid may enhance the 
Table 1. Comparison of MB adsorption rate by B. pseudomycoides JH 2-2, C. freundii JH 11-2 and other reported bacteria

\begin{tabular}{|c|c|c|c|c|c|c|c|}
\hline \multirow{2}{*}{ Content } & \multirow{2}{*}{ Dye } & \multicolumn{4}{|c|}{ Operating conditions } & \multirow{2}{*}{$q_{e}(\mathrm{mg} / \mathrm{g})$} & \multirow{2}{*}{ Ref. } \\
\hline & & $\mathrm{pH}$ & $M^{*}$ & $\mathrm{~V}^{* *}$ & Equilibrium & & \\
\hline P. notatum, & \multirow{6}{*}{ MB } & 8.0 & $0.01 \mathrm{~g}$ & $30 \mathrm{ml}$ & $6 \mathrm{~h}$ & 33.6 & Kumar and Porkodi, 2007 \\
\hline P. oceanica & & 6.0 & $0.4 \mathrm{~g}$ & $50 \mathrm{ml}$ & $3 \mathrm{~h}$ & 4.64 & Ncibi et al., 2007 \\
\hline C. glutamicum & & 9.0 & $0.1 \mathrm{~g}$ & $40 \mathrm{ml}$ & $12 \mathrm{~h}$ & 207.3 & Vijayaraghavan et al., 2008 \\
\hline E. spp. & & 6.0 & $0.05 \mathrm{~g}$ & $50 \mathrm{ml}$ & $3 \mathrm{~h}$ & 273.73 & Ncibi et al., 2009 \\
\hline C. freundii & & 9.0 & $0.15 \mathrm{~g}$ & $100 \mathrm{ml}$ & $10 \mathrm{~min}$ & 954 & This work \\
\hline B. pseudomycoides & & 9.0 & $0.1 \mathrm{~g}$ & $100 \mathrm{ml}$ & $30 \mathrm{~min}$ & 1072.4 & This work \\
\hline
\end{tabular}

*M-biomass dose

**V- Volume

(a)

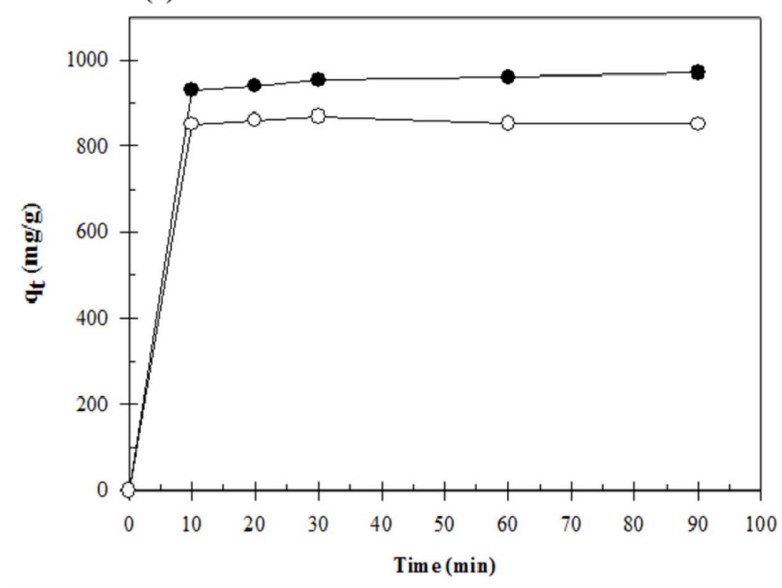

(b)

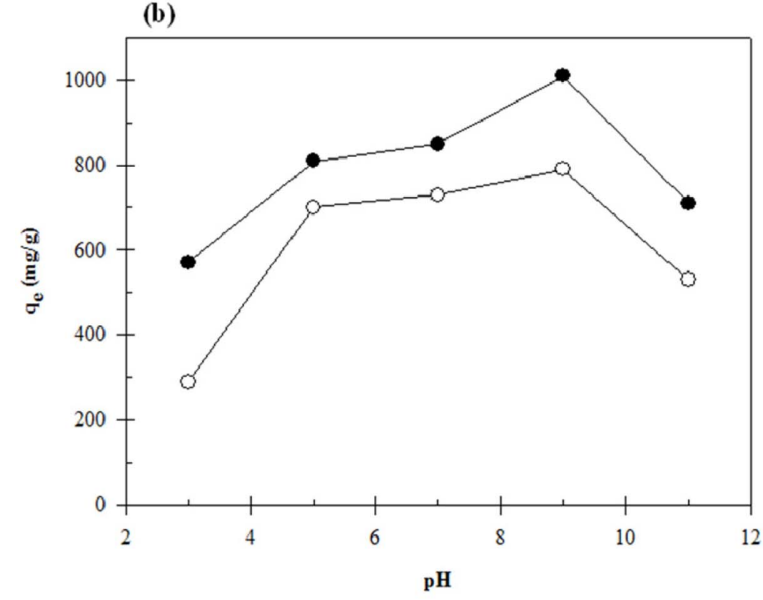

Fig. 5. (a) MB adsorption onto C. freundii JH 11-2 dried and UV$\mathrm{C}$ treated biomass under optimized condition (b) Effect of initial $\mathrm{pH}$ on removal of MB by $C$. freundii JH 11-2 (dye concentration, $1100 \mathrm{mg} / \mathrm{L}$; $\mathrm{pH}$, 9; amount of biomass, $0.15 \mathrm{~g}$; dried biomass $(\bigcirc)$; UV-C treatment biomass $(\mathbf{O})$ ).

adsorption rate of $\mathrm{MB}$ in Gram-positive bacteria $B$. pseudomycoides JH 2-2.

J. Soil Groundw. Environ. Vol. 19(2), p. 38 43, 2014

\section{Conclusion}

C. freundii $\mathrm{JH}$ 11-2 and B. pseudomycoides $\mathrm{JH} 2-2$ biomass were used for the removal of $\mathrm{MB}$ in aqueous solution under optimum conditions. Maximum biosorption of MB was observed in the UV pretreated $C$. freundii JH 11-2 and B. pseudomycoides JH 2-2 biomass were 954 and $1072.4 \mathrm{mg} / \mathrm{g}$, respectively. The physico-chemical variables greatly influence the biosorption. This study indicated the scope of the wastewater recycling using bacterial biomass.

\section{References}

Aksu, Z. and Tezer, S., 2005, Biosorption of reactive dyes on the green alga Chlorella vulgaris, Process. Biochem., 40(3), 13471361.

Aleboyeh, A., Daneshvar, N., and Kasiri, M.B., 2008, Optimization of CI Acid Red 14 azo dye removal by electrocoagulation batch process with response surface methodology, Chem. Eng. Process.: Proc. Intensification, 47(5), 827-832.

Arami, M., Limaee, N.Y., Mahmoodi, N.M., and Tabrizi, N.S., 2005, Removal of dyes from colored textile wastewater by orange peel adsorbent: equilibrium and kinetic studies, J. Coll. Int. Sci., 288(2), 371-376.

Avom, J., Mbadcam, J.K., Noubactep, C., and Germain, P., 1997, Adsorption of methylene blue from an aqueous solution on to activated carbons from palm-tree cobs, Carbon, 35(3), 365-369.

Bayramoğlu, G. and Arıca, M.Y., 2007, Biosorption of benzidine based textile dyes "Direct Blue 1 and Direct Red 128" using native and heat-treated biomass of Trametes versicolor, $J$. Hazard. Mater, 143(1), 135-143.

Chiou, M.S. and Li, H.Y., 2003, Adsorption behavior of reactive dye in aqueous solution on chemical cross-linked chitosan 
beads, Chemosphere, 50(8), 1095-1105.

Çolak, F., Atar, N., and Olgun, A., 2009, Biosorption of acidic dyes from aqueous solution by Paenibacillus macerans: Kinetic, thermodynamic and equilibrium studies, Chem. Eng. J., 150, 122-130.

Crini, G., 2006, Non-conventional low-cost adsorbents for dye removal: a review, Biores. Tech., 97(9), 1061-1085.

Eccles, H., 1995, Removal of heavy metals from effluent streams-why select a biological process?, Int. Biodeter. Biodeg., 35(1), 5-16.

Franz, C.M., Specht, I., Cho, G.S., Graef, V., and Stahl, M.R., 2009, UV-C-inactivation of microorganisms in naturally cloudy apple juice using novel inactivation equipment based on Dean vortex technology, Food Cont., 20(12), 1103-1107.

Ghosh, D. and Bhattacharyya, K.G., 2002, Adsorption of methylene blue on kaolinite, Appl. Clay Sci., 20(6), 295-300.

Guillard, C., Disdier, J., Monnet, C., Dussaud, J., Malato, S., Blanco, J., and Herrmann, J.M., 2003, Solar efficiency of a new deposited titania photocatalyst: chlorophenol, pesticide and dye removal applications, Appl. Catal. B-Environ., 46(2), 319-332.

Gupta, V.K., Suhas, A.I., and Saini, V.K., 2004, Removal of rhodamine $\mathrm{B}$, fast green, and methylene blue from waste water using red mud, an aluminum industry waste, Ind. Eng. Chem. Res., 43(7), 1740-1747.

Hameed, B.H., Din, A.M., and Ahmad, A.L., 2007, Adsorption of methylene blue onto bamboo-based activated carbon : Kinetics and equilibrium studies, J. Hazard. Mater., 141(3), 819-825.

Ip, A.W.M., Barford, J.P., and McKay, G., 2009, Reactive Black dye adsorption/desorption onto different adsorbents: effect of salt, surface chemistry, pore size and surface are, J. Coll. Int. Sci., 337(1), 32-38.

Janoš, P., 2003, Sorption of basic dyes onto iron humate, Env. Sci. Tech., 37(24), 5792-5798.

Kumar, K.V. and Porkodi, K., 2007, Mass transfer, kinetics and equilibrium studies for the biosorption of methylene blue using Paspalum notatum, J. Hazard. Mater., 146, 214-226.

Nataraj, S.K., Hosamani, K.M., and Aminabhavi, T.M., 2009, Nanofiltration and reverse osmosis thin film composite membrane module for the removal of dye and salts from the simulated mixtures, Desalination, 249(1), 12-17.

Ncibi, M.C., Mahjoub, B., and Seffen, M., 2007, Kinetic and equilibrium studies of methylene blue biosorption by Posidonia oceanica (L.) fibres, J. Hazard. Mater, 139, 280-285.

Ncibi, M., Hamissa, A., Fathallah, A., Kortas, M., Baklouti, T., Mahjoub, B., and Seffen, M., 2009, Biosorptive uptake of meth- ylene blue using Mediterranean green alga Enteromorpha spp., J. Hazard. Mater., 170, 1050-1055.

Mera, M.U., Kemper, M., Doyle, R., and Beveridge, T.J.,1992, The membrane-induced proton motive force influences the metal binding ability of Bacillus subtilis cell walls, Appl.Eenviron.Microbiol., 58(12), 3837-3844.

McMullan, G., Meehan, C., Conneely, A., Kirby, N., Robinson, T., Nigam, P., and Smyth, W., 2001, Microbial decolourisation and degradation of textile dyes, Appl. Microbiol. Biot., 56(1-2), 81-87.

Morais, L.C., Freitas, O.M., Goncalves, E.P., Vasconcelos, L.T., and Gonzalez Beca, C.G., 1999, Reactive dyes removal from wastewaters by adsorption on eucalyptus bark: variables that define the process, Water Res., 33(4), 979-988.

Pavia, D., Lampman, G., Kriz, G., and Vyvyan, J., 2008, Introduction to spectroscopy. Cengage Learning.

Pearce, C.I., Lloyd, J.R., and Guthrie, J.T., 2003, The removal of color from textile wastewater using whole bacterial cells: a review, Dye pigments, 58(3), 179-196.

Romero González, M.E., Williams, C.J., and Gardiner, P.H., 2001, Study of the mechanisms of cadmium biosorption by dealginated seaweed waste, Environ. Sci. Technol., 35(14), 3025-3030.

Sies, H., Schulz, W.A., and Steenken, S., 1996, Adjacent guanines as preferred sites for strand breaks in plasmid DNA irradiated with $193 \mathrm{~nm}$ and $248 \mathrm{~nm}$ UV laser light, J. Photoch. Photobio. B., 32(1), 97-102.

Song, N., Guo, W.B., Zhu, Z.Z., Liu, G.J., and Qiao, B., 2009, Choice of the Instructions Microbiology in Urban Sewage under Ultraviolet Disinfection, Liaoning Chem. Ind., 7, 014.

Vijayaraghavan, K. and Yun, Y.S., 2007, Utilization of fermentation waste (Corynebacterium glutamicum) for biosorption of reactive black 5 from aqueous solution, J. Hazard. Mater., 141(1), 45-52.

Vijayaraghavan, K., Won, S.W., Mao, J., and Yun, Y.S., 2008, Chemical modification of Corynebacterium glutamicum to improve methylene blue biosorption, Chem.Eng. J., 145, 1-6.

Widmann, C., Gibson, S., and Johnson, G.L., 1998, Caspasedependent cleavage of signaling proteins during apoptosis A turn-off mechanism for anti-apoptotic signals, J. Biol. Chem., 273(12), 7141-7147.

Zimmer, J.L. and Slawson, R.M., 2002, Potential repair of Escherichia coli DNA following exposure to UV radiation from both medium-and low-pressure UV sources used in drinking water treatment, Appl. Environ. Microb., 68(7), 3293-3299. 